\title{
Molecular identification of abomasal bacteria associated with resistance and susceptibility to Haemonchus contortus infection in sheep
}

\section{Identificação molecular de bactérias abomasais associadas à resistência e susceptibilidade a infecções por Haemonchus contortus em ovinos}

\author{
Adriane Holtz Tirabassi ${ }^{1}$; Humberto Maciel França Madeira ${ }^{2}$; \\ Stenio Perdigão Fragoso ${ }^{3}$; Adriana Castilhos Souza Umaki ${ }^{4}$; Rodrigo Egevardt ${ }^{5}$; \\ Talita Melo ${ }^{5}$; João Filipi Pereira ${ }^{1}$; Valéria Natasha Teixeira ${ }^{6}$; \\ Rüdiger Daniel Ollhoff ${ }^{2}$; Cristina Santos Sotomaior ${ }^{2 *}$
}

\begin{abstract}
The widespread occurrence of anthelmintic-resistant gastrointestinal nematodes (GINs), particularly Haemonchus contortus, in sheep production systems has magnified the need to identify and develop alternative control strategies. Strategies include the selection of genetically GIN-resistant sheep and the implementation of biological parasite control to reduce dependence on anthelmintic drugs. In this study, we aimed to establish the molecular identity of bacterial communities present in the abomasum of sheep classified as resistant or susceptible to $H$. contortus. Thirty-eight sheep were experimentally infected with L3 Haemonchus contortus and analyzed for fecal egg count (FEC), and hematocrit (Ht) to establish haemonchosis resistance or susceptibility. Four resistant sheep (RS) and four susceptible sheep (SS) were selected for microbial sampling and subsequent phylogenetic analysis. Molecular identification of the bacteria was based on amplification of the bacterial 16S rRNA gene, construction of a $16 \mathrm{~S}$ rDNA clone library, and subsequent gene sequencing. Significant differences $(p=0.05)$ were observed in the occurrence of different phyla identified in RS and SS libraries: Firmicutes $(61.4 \%$ and $37.2 \%$, respectively), Proteobacteria ( $10.2 \%$ and $37.2 \%$, respectively), Bacteroidetes $(12.8 \%$ and $5.8 \%$, respectively), and unclassified bacteria (12.8\% and $17 \%$, respectively). Differences between the proportions of bacterial communities present in the RS and SS pool samples were observed, contributing as a first step toward the assessment of the association between the gastrointestinal tract microbiota and nematode resistance in sheep.
\end{abstract}

Key words: Abomasum. Gastrointestinal nematodes. Resistance. Susceptibility. 16S rRNA.

\footnotetext{
${ }^{1}$ Discentes, Programa de Pós-Graduação em Ciência Animal, PPGCA, Pontifícia Universidade Católica do Paraná, PUCPR, Curitiba, PR, Brasil. E-mail: adriane_ht@yahoo.com.br; joao.filipi@gmail.com

2 Profs., Programa de Pós-Graduação em Ciência Animal, PPGCA, PUCPR, Curitiba, PR, Brasil. E-mail: h.madeira@pucpr.br; ollhoff@gmail.com; cristina.sotomaior@pucpr.br

${ }^{3}$ Pesquisador, Fundação Oswaldo Cruz, Fiocruz, Curitiba, PR, Brasil. E-mail: sfragoso@fiocruz.br

${ }^{4}$ Pesquisador, Instituto de Biologia Molecular do Paraná, IBMP, Curitiba, PR, Brasil. E-mail: acsumaki@tecpar.br

5 Discentes, Curso de Medicina Veterinária, Pontifícia PUCPR, Curitiba, PR, Brasil. E-mail: rodrigo18egevardt@hotmail.com; talitamelo88@hotmail.com

${ }^{6}$ Prof $^{a}$, Curso de Medicina Veterinária, PUCPR, Curitiba, PR, Brasil. E-mail: valeria.natascha@pucpr.br

* Author for corresponence
} 


\title{
Resumo
}

\begin{abstract}
Na produção de ovinos, a disseminação de nematódeos gastrintestinais (NGI) resistentes aos antihelmínticos, em especial Haemonchus contortus, tem levado à busca de estratégias de controle alternativo, como a seleção de animais geneticamente resistentes aos NGI e o controle biológico. Neste trabalho, buscou-se identificar molecularmente as comunidades bacterianas presentes no abomaso de animais classificados como resistentes ou susceptíveis ao $H$. contortus. Foram utilizados 38 ovinos para classificação em resistentes ou susceptíveis à hemoncose, por meio de infecções experimentais com L3 de H. contortus e posterior análise de variações na contagem de ovos por grama de fezes $(\Delta \mathrm{OPG})$ e hematócrito $(\Delta \mathrm{Ht})$. Destes, foram selecionados para colheita de material e posterior análise filogenética, quatro ovinos resistentes (OR) e quatro susceptíveis (OS). A identificação molecular de bactérias foi realizada por técnicas moleculares a partir da amplificação do gene RNAr 16S bacteriano, construção de bibliotecas de clones de RNAr 16S e posterior sequenciamento gênico. O trabalho mostrou diferença significativa $(\mathrm{p}=0,05)$ na porcentagem dos filos predominantes para as bibliotecas OR e OS, respectivamente: Firmicutes (61,4\% e 37,2\%), Proteobacterias (10,2\% e 37,2\%), Bacteroidetes (12,8\% e 5,8\%) e Bactérias não classificadas (12,8\% e 17\%). Diferenças entre os pools OR e OS com relação à proporção de comunidades bacterianas presentes podem ser observadas, sendo o primeiro passo para que se possa avaliar a relação entre a microbiota do trato gastrointestinal e a resistência a parasitos.

Palavras-chave: Abomaso. Nematódeos gastrointestinais. Resistência. RNAr 16S. Susceptibilidade.
\end{abstract}

\section{Introduction}

Infections caused by gastrointestinal nematodes (GINs), particularly the abomasal parasite Haemonchus contortus, damage sheep production, causing significant economic losses, especially in tropical and subtropical regions worldwide (SYKES, 1994). The use of anthelmintic drugs to treat GIN infections causes a strong selective pressure among parasitic nematodes, resulting in the emergence of anthelmintic-resistant strains, even to monepantel, the newest drug available (THOMAZ-SOCCOL et al., 2004; TORRESACOSTA et al., 2012; VAN DEN BROM et al., 2015). Therefore, alternative control strategies are being explored to decrease the dependency on anthelmintic drugs, reduce production costs, and promote increases in animal production (BISHOP, 2012).

Genetically GIN-resistant animal selection and biological parasite control are important alternatives to drug treatment. Genetic resistance to GIN infection is well documented in various breeds, and resistance traits can be determined and selected for (BISHOP; MORRIS, 2007; SOTOMAIOR et al., 2007). According to Bishop and Stear (2003), resistance to infection is regulated mainly by the ability of the host to interact with and control the life cycle of the parasite. Most studies of genetic resistance use fecal egg count (FEC) as the indicator trait for resistance (BISHOP; MORRIS, 2007; JACKSON; MILLER, 2006; SADDIQI et al., 2012).

The use of biological control agents that possess anthelmintic effects presents advantages over traditional chemotherapeutic approaches, including the absence of chemical residues and prevention of resistance to conventional drugs (SCHNEPF et al., 1998). Studies regarding GIN control have focused primarily on Bacillus thuringiensis (O'GRADY et al., 2007), which demonstrated anthelmintic efficacy against the larvae and adults of the three predominant GIN parasites in sheep: H. contortus, Trichostrongylus colubriformes, and Teladorsagia circumcincta (KOTZE et al., 2005).

To date, little is known about the microbial diversity of the sheep abomasum, an important site of nematode infection, much less the correlation between this diversity and GIN resistance. Thus, this work aimed to identify the bacterial communities present in the abomasum of animals 
classified as genetically GIN resistant or GIN susceptible to $H$. contortus infection.

\section{Materials and Methods}

\section{Animals}

We used 38 adult mixed-breed (Ile de France and Texel crosses) nonpregnant female sheep. All ewes belonged to the sheep-breeding herd of the Pontifical Catholic University of Paraná (PUCPR) Experimental Farm located in the city of Fazenda Rio Grande, State of Paraná, Brazil. This study was approved by the Research Ethics Committee of Pontifícia Universidade Católica do Paraná, under the protocols 558 and 747.

\section{Experimental infection}

Pure cultures of $H$. contortus were obtained to perform experimental infections. Initially, after slaughtering a male lamb, the abomasum was removed, and female $H$. contortus were collected manually and placed in $42^{\circ} \mathrm{C}$ water for $24 \mathrm{~h}$ to lay eggs. Eggs were placed in autoclaved shavings for 7 $\mathrm{d}$ in a biochemical oxygen demand (BOD) incubator at $26^{\circ} \mathrm{C}$, and the larvae were subsequently recovered for quantification and identification (ROBERTS; O'SULLIVAN, 1950). Four ewe lambs that were free from GINs were infected with the larvae obtained in the previous step, and L3 larvae were obtained by coproculture according to the methods described by Roberts and O'Sullivan (1950).

Thirty-eight ewes were dewormed with $7.5 \mathrm{mg} /$ $\mathrm{kg}$ of levamisole. Following deworming and FEC analysis (GORDON; WHITLOCK, 1939), animals were infected with individual doses of 25,000 L3 H. contortus larvae. After infection (day 0), the ewes were sampled on days 14, 21, 28, 42, and 56 to perform FEC analysis (GORDON; WHITLOCK, 1939) and hematocrit (Ht) analysis (JAIN, 1986).

Statistical analysis of the average $\mathrm{Ht}$ and FEC obtained during the 56-day experimental infection period was performed using analysis of variance (ANOVA), in a completely randomized design, with two sources of variation (PCV and FEC) in repeated measurements, using the software Statgraphics ${ }^{\circledR}$ Centurion XVI, version 16.1.11. (StatPoint Technologies, Inc. Warrenton, Virginia), followed by Tukey's test with 5\% level of significance. Mean FEC values were transformed by $\log 10(x+1)$ for the statistical analysis.

\section{Classification of H. contortus-resistant and -susceptible sheep}

Ewes were grouped as either $H$. contortusresistant or -susceptible according to their response to experimental infection with $H$. contortus larvae, based on the variation in FEC and Ht values after the 56-day evaluation period. $\triangle \mathrm{FEC}$ was calculated for each ewe corresponding to the FEC value on the last day of evaluation (day 56) minus the FEC value on day $0 . \Delta \mathrm{Ht}$ values were determined as $\mathrm{Ht}$ on day 0 minus Ht on day 56. Ewes with lower $\triangle \mathrm{FEC}$ and $\Delta \mathrm{Ht}$ were considered more resistant. Conversely, ewes with higher $\triangle \mathrm{FEC}$ and $\triangle \mathrm{Ht}$ were considered more susceptible.

\section{Molecular identification of abomasal bacteria}

Abomasal contents were collected by ultrasonographic image-guided (Aloka SSD 500 Ultrasound) abdominal puncture. Briefly, animals were sedated with intravenous diazepam (5 mg/mL), given local anesthesia (lidocaine hydrochloride, $2 \mathrm{mg} / \mathrm{mL}$ ), and placed in left lateral decubitus. Following local trichotomy and antisepsis, a puncture was performed at approximately $2 \mathrm{~cm}$ caudal to the xiphoid process and $1 \mathrm{~cm}$ dorsal to the abdominal midline, and contents were drawn using size 14 catheters and $30-\mathrm{mL}$ syringes. Contents were determined to be abomasal if the $\mathrm{pH}$ of the sample ranged from 2 to 4. The collected abomasal contents were stored in sterile $50-\mathrm{mL}$ Falcon tubes at $-20^{\circ} \mathrm{C}$. 
For molecular identification of abomasal bacteria, total DNA was extracted from the abomasal contents. The samples were preprocessed by washing via differential centrifugation, and DNA extraction was performed by physical disruption of the cells using BeadBeater (Biospec Products; Bartlesville, OK, USA) in the presence of sodium dodecyl sulfate (SDS) and lysozyme (SAMBROOK; RUSSEL, 2001). The final DNA concentration of samples from all animals was standardized to $20 \mathrm{ng} / \mathrm{mL}$ and then grouped into two DNA pools based on the previous selection of animals, i.e., resistant sheep (RS) and susceptible sheep (SS). The 16S rDNA gene was amplified by polymerase chain reaction (PCR) using primers 27F (5'-AGAGTTTGATCCTGGCTCAG-3') and 1492R (5'-GGTTACCTTGTTACGACTT-3') in a final reaction volume of $50 \mu \mathrm{L}(50 \mathrm{mM} \mathrm{MgCl}$, $1.25 \mathrm{mM}$ dNTPs, $20 \mathrm{pmol} / \mu \mathrm{L}$ of each primer, $5 \mathrm{U}$ Taq DNA polymerase, $20 \mathrm{ng} / \mu \mathrm{L}$ template DNA), according to the method of Patel et al. (2011). Amplification reaction conditions were as follows: one cycle at $94^{\circ} \mathrm{C}$ for $5 \mathrm{~min} ; 30$ cycles of $94^{\circ} \mathrm{C}$ for $30 \mathrm{~s}, 55^{\circ} \mathrm{C}$ to $57^{\circ} \mathrm{C}$ for $30 \mathrm{~s}$ (the temperature here varied according to the amplified pool), and $72^{\circ} \mathrm{C}$ for $2 \mathrm{~min}$; and a final cycle at $72^{\circ} \mathrm{C}$ for $7 \mathrm{~min}$.

Clone libraries of 16S rDNA genes were constructed by ligating PCR amplified sequences to the pCR2.1 vector and transforming them into Escherichia coli TOP10 One Shot chemically competent cells (Invitrogen, Carlsbad, CA, USA) according to the manufacturer's instructions. Plasmid DNA was extracted from 20 clones of each library using the QIAprep Spin Miniprep Kit (Qiagen, Valencia, CA, USA) according to the manufacturer's instructions. The 16S rDNA genes were partially sequenced at a commercial laboratory (Macrogen, South Korea) using the T7 promoter (5'-TAATACGACTCACTATAGGG-3') and M13 (5'-CAGGAAACAGCTATGAC-3') primers. The obtained 16S rRNA sequences were compared with those available in the Ribosomal Database Project (RDPII) Release 10, Update 32 (http://rdp.cme. msu.edu/) using the CLASSIFIER algorithm, with confidence of $85 \%$ or above. The distribution of the identified phyla in the RS and SS groups was compared using a chi-square test $(5 \%$ significance level).

\section{Results and Discussion}

Results from the experimental infection of 38 ewes with $H$. contortus larvae are summarized in Table 1. Compared with day 0 , the average $\mathrm{Ht}$ values on days 14,21 , and 28 postinfection were not altered; however, a decrease $(\mathrm{p}<0.05)$ in the average values was observed beginning on day 42 . The FEC values progressively increased after each evaluation day starting at day 0 , and this increase was statistically significant $(\mathrm{p}<0.05)$ on days 28 and 56 postinfection. The majority of studies that address genetic resistance between individuals belonging to the same breed use FEC values as indicators of resistance (BISHOP; MORRIS, 2007). $\mathrm{Ht}$ is another important indicator of resistance and is negatively correlated with FEC values; moreover, Ht reduction may depict a more accurate picture of the infection's severity (SHAKYA et al., 2011). According to Saddiqi et al. (2012), low Ht values are commonly associated with high FEC values due to sucking of copious amounts of blood from the abomasum by adult parasites.

Based on $\triangle \mathrm{FEC}$ and $\triangle \mathrm{Ht}$ the ewes were classified into two distinct groups, resistant and susceptible. Frequently, the term "disease resistant" is used to describe not only the host's resistance to the infection, but also resistance to the disease consequences of infection, that is, disease tolerance (BISHOP, 2012). According the terminology of Bishop and Stear (2003), resistance to infection essentially describes the host's ability to interact with and control the lifecycle of the parasite. In the context of nematode infections, this may include the establishment probabilities of ingested larvae, rate and extent of parasite development within the host, parasite mortality, 
and parasite fecundity and, hence, the FEC. Resilience is related to tolerance and describes an Disease tolerance is often used to describe a host's animal's ability to maintain performance in the ability to withstand pathogenic effects of infection. face of a disease challenge.

Table 1. Mean and standard deviation (SD) of hematocrit (Ht) and fecal egg count (FEC) values of 38 ewes, experimentally infected with L3 Haemonchus contortus, at different days postinfection.

\begin{tabular}{ccccc}
\hline Day & Ht & SD & FEC & SD \\
\hline 0 & $32.11^{\mathrm{ab}}$ & \pm 3.29 & $15.79^{\mathrm{a}}$ & \pm 48.08 \\
14 & $33.84^{\mathrm{a}}$ & \pm 2.92 & $60.53^{\mathrm{a}}$ & \pm 106.01 \\
21 & $33.60^{\mathrm{a}}$ & \pm 4.02 & $513.16^{\mathrm{a}}$ & \pm 681.09 \\
28 & $31.11^{\mathrm{b}}$ & \pm 6.82 & $4389.47^{\mathrm{b}}$ & \pm 4099.77 \\
42 & $27.87^{\mathrm{c}}$ & \pm 4.46 & $6605.26^{\mathrm{bc}}$ & \pm 5292.85 \\
56 & $27.47^{\mathrm{c}}$ & \pm 3.99 & $7246.05^{\mathrm{c}}$ & \pm 6191.19 \\
\hline
\end{tabular}

Note: different letters in the same column indicate significantly different values by Tukey's test (5\% significance level).

The characteristics of the eight ewes that were selected for microbial analysis (resistant, $\mathrm{n}=4$; susceptible, $n=4$ ) are described in Table 2. The primary criterion for the selection of the animals was the FEC variation because it represents the infection level of experimentally infected animals (BISHOP; STEAR, 2003; GOOD et al., 2006). The secondary criterion, Ht variation, indicates different levels of infection, which is manifested clinically as anemia that can be verified by hematologic tests (SADDIQI et al., 2012).

Table 2. Animal and infection characteristics of $H$. contortus-resistant ewes $(\mathrm{n}=4)$ and $H$. contortus-susceptible ewes $(n=4)$.

\begin{tabular}{|c|c|c|c|c|c|c|c|}
\hline & $\begin{array}{c}\text { Age } \\
\text { (years) }\end{array}$ & $\begin{array}{c}\text { FEC } \\
\text { D0 } \\
\end{array}$ & $\begin{array}{l}\text { FEC } \\
\text { D56 }\end{array}$ & $\begin{array}{c}\Delta \mathbf{F E C} \\
(\mathrm{D} 56-\mathrm{D} 0)\end{array}$ & $\begin{array}{l}\mathbf{H t} \\
\mathrm{D} 0\end{array}$ & $\begin{array}{c}\mathbf{H t} \\
\text { D56 }\end{array}$ & $\begin{array}{c}\Delta \mathbf{H t} \\
\text { (D0 - D56) }\end{array}$ \\
\hline \multicolumn{8}{|c|}{ Resistant animals } \\
\hline Animal 1 & 3 & 50 & 0 & -50 & 33.0 & 33.0 & 0.0 \\
\hline Animal 2 & 2 & 0 & 0 & 0 & 30.0 & 34.0 & -4.0 \\
\hline Animal 3 & 2 & 0 & 200 & 200 & 31.0 & 31.0 & 0.0 \\
\hline Animal 4 & 3 & 0 & 250 & 250 & 34.0 & 31,0 & 3.0 \\
\hline \multicolumn{8}{|c|}{ Susceptible animals } \\
\hline Animal 1 & 3 & 0 & 14900 & 14900 & 35.0 & 24.0 & 11.0 \\
\hline Animal 2 & 4 & 50 & 16700 & 16650 & 33.0 & 23.0 & 10.0 \\
\hline Animal 3 & 3 & 0 & 18350 & 18350 & 37.0 & 30.0 & 7.0 \\
\hline Animal 4 & 4 & 0 & 14400 & 14400 & 37.0 & 32.0 & 5.0 \\
\hline
\end{tabular}

Notes:

FEC - fecal egg count

$\mathrm{Ht}$ - hematocrit

D0 - day 0 postinfection

D56 - day 56 postinfection. 
Amplification of the 16S rDNA from abomasal contents yielded a product of approximately 1.4 $\mathrm{kb}$, consistent with the expected size of amplicons. From each clone library (RSs and SSs), 20 clones were randomly selected for sequencing, and sequences of approximately $1400 \mathrm{bp}$ were obtained for most samples. Following sequence trimming for vector DNA and low quality ends, fragments with an average size of $900 \mathrm{bp}$ were analyzed using the CLASSIFIER algorithm, which allowed for the classification of bacteria into different phylogenetic levels (Table 3). The lowest level that was possible to classify the sequences into was the family level. In some instances, due to sequence quality and length, sequences could only be classified down to the order or class level.

Table 3. Phylogenetic classification of bacterial sequences obtained from 16S rDNA libraries generated from extracted DNA of abomasal contents of resistant sheep (RS) and susceptible sheep (SS).

\begin{tabular}{|c|c|c|c|c|c|}
\hline \multicolumn{4}{|c|}{ Bacteria } & \multicolumn{2}{|c|}{ Number of } \\
\hline Filo & Class & Ordem & Family & RS & SS \\
\hline \multirow[t]{10}{*}{ Firmicutes } & Negativicutes & Selenomonadales & & & 2 \\
\hline & & Selenomonadales & Acidaminococcaceae & 4 & \\
\hline & Bacilli & Lactobacillales & & & 7 \\
\hline & & & Lactobacillaceae & 1 & \\
\hline & & & unclassified Lactobacilalles & 1 & \\
\hline & Clostridia & Clostridiales & & & 3 \\
\hline & & & Lachnospiraceae & 6 & \\
\hline & & & Ruminococcaceae & 10 & \\
\hline & & & unclassified Clostridiales & 2 & \\
\hline & Unclassified Firmicutes & & & & 1 \\
\hline Total & & & & 24 & 13 \\
\hline \multirow[t]{6}{*}{ Proteobacteria } & Alphaproteobacteria & Rhodospirillales & & & 1 \\
\hline & & Rhizobiales & Acetobacteraceae & 2 & \\
\hline & Betaproteobacteria & Burkholderiales & & & 8 \\
\hline & & Burkholderiales & Comamonadaceae & 1 & \\
\hline & & & unclassified Burkholderiales & 1 & \\
\hline & Gammaproteobacteria & Enterobacteriales & & & 4 \\
\hline Total & & & & 4 & 13 \\
\hline \multirow[t]{2}{*}{ Bacteroidetes } & Bacteroidia & Bacteroidales & & & 2 \\
\hline & & & unclassified Bacteroidales & 3 & \\
\hline & unclassified Bacteroidetes & & & 2 & \\
\hline Total & & & & 5 & 2 \\
\hline Actinobacteria & Actinobacteria & & & & 1 \\
\hline Total & & & & $\mathbf{0}$ & 1 \\
\hline Verrucomicrobia & Subdivision5 & & & 1 & \\
\hline Total & & & & 1 & $\mathbf{0}$ \\
\hline unclassified bacteria & & & & 5 & 6 \\
\hline Total & & & & 6 & 11 \\
\hline unclassified root & & & & 1 & 5 \\
\hline Total & & & & 1 & 5 \\
\hline Total of sequences & & & & 40 & 40 \\
\hline
\end{tabular}


Figure 1 shows the results of the taxonomic distribution of the sequences from the RS and SS libraries. The RS- and SS-derived sequences were distributed into five phylogenetic groups: Firmicutes $(61.4 \%$ and $37.2 \%$, respectively), Proteobacteria (10.2\% and $37.2 \%$, respectively), Bacteroidetes (12.8\% and 5.8\%, respectively), Verrucomicrobia
( $2.8 \%$, only in RS), Actinobacteria ( $2.8 \%$, only in SS), and unidentified bacteria (12.8\% and $17 \%$, respectively). The proportions of phyla were significantly different in the RS and SS groups (p $=0.05$ ). Firmicutes was the predominant phylum in the SS group. In the RS group, the Firmicutes and Proteobacteria phyla were the predominant phyla and were present in equivalent amounts.

Figure 1. Distribution of predominant phyla for the 16S rRNA gene libraries of the resistant sheep (RS) and susceptible sheep (SS) DNA pools.

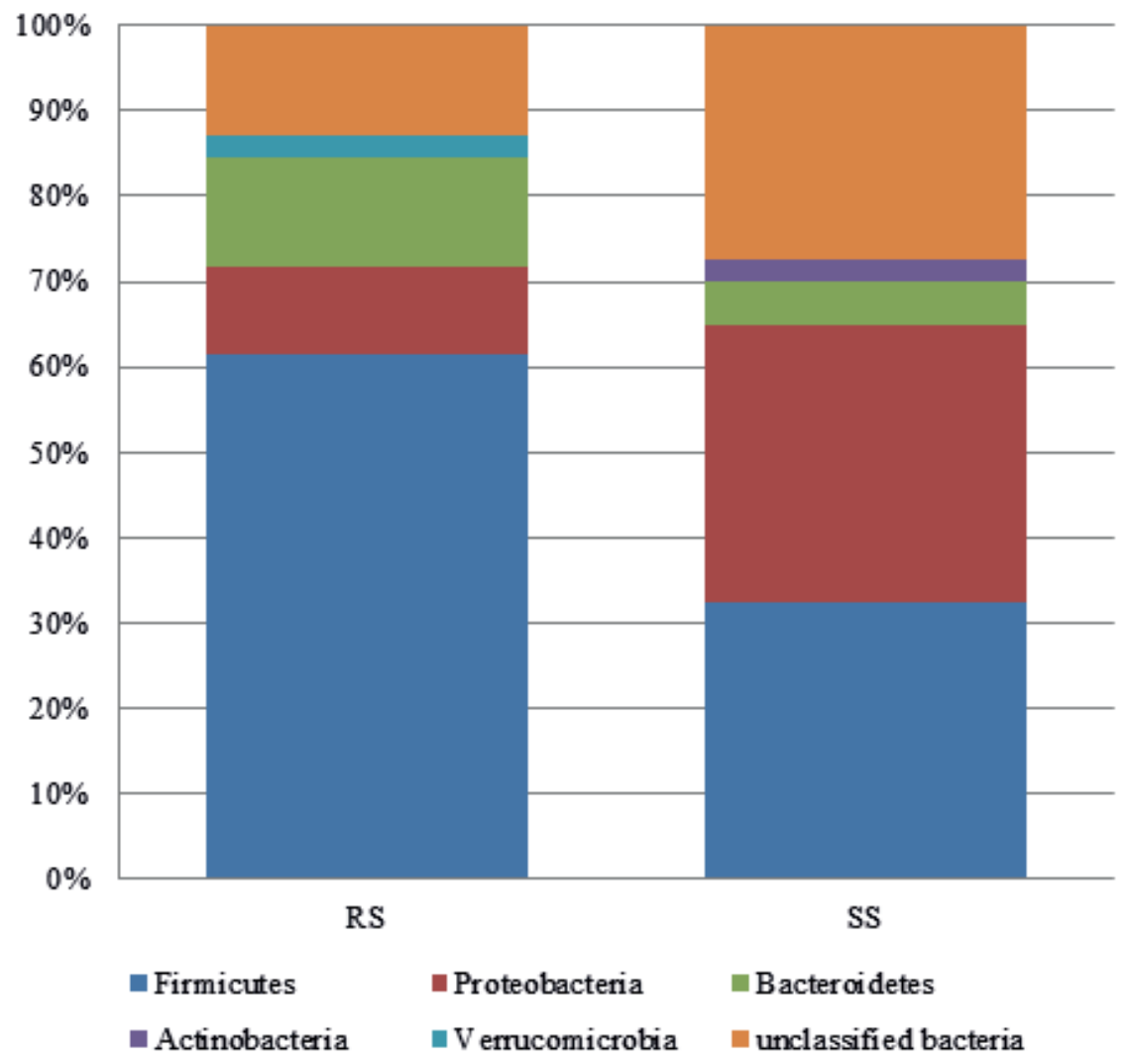

Results for the RS group were similar to the predominant bacterial communities in ruminal fluid (EDWARDS et al., 2004; CUNHA et al., 2011; KIM et al., 2011) and the abomasal content in sheep (TIRABASSI, 2013). This similarity may be because bacteria from the rumen are viable in the abomasum (SIMCOCK et al., 1999, 2006) and ruminal bacteria, alive or dead, may have their DNA amplified by PCR of the abomasal contents
(SINNATHAMBY, 2012). According to LaporteUribe and Gibbs (2009), while the microflora profiles of rumen and abomasal samples have strong similarities, as might be expected, notable differences appear to occur which have not been described in the literature to date. These differences suggest subpopulations of rumen bacteria are differentially retained in the rumen, while also residing within the abomasum. 
Results from the SS group were more similar to bacterial results reported in adult $H$. contortus (TIRABASSI, 2013), possibly because $H$. contortus exists in the abomasal environment in large quantities in susceptible animals and was collected in large quantities at the time of the material collection. According to the work of Sinnathamby (2012), the predominant phyla identified in adult $H$. contortus are Firmicutes (44\%), Proteobacteria (40\%), and Bacteroidetes (16\%). In contrast to resistant animals, susceptible sheep have a greater FEC and parasite load (BISSET et al., 1994). Therefore, the bacterial community in susceptible animals may present distinct characteristics. According to Li et al. (2011), Ostertagia ostertagi infection in cattle seemingly had a minimal impact on the abomasal microbial diversity at a genus level in immune animals, when compared to a control group. This observation demonstrated that immune animals might have developed the ability to maintain stability of the abomasal microbiota ecosystem.

The distribution of classes belonging to the predominant phyla of the analyzed libraries is shown in Figure 2. The distribution of classes within the predominant phyla was similar for the RS and SS pools. However, in the Proteobacteria phylum, Gammaproteobacteria appear in the SS group, which is similar to the distribution of Gammaproteobacteria in parasite pools, characterized by its absence in the abomasal content and mucosa (TIRABASSI, 2013) and by a lower predominance of Betaproteobacteria.

Figure 2. Distribution of the classes within the predominant phyla based on 16S rDNA gene libraries of resistant sheep (RS) and susceptible sheep (SS) counts.

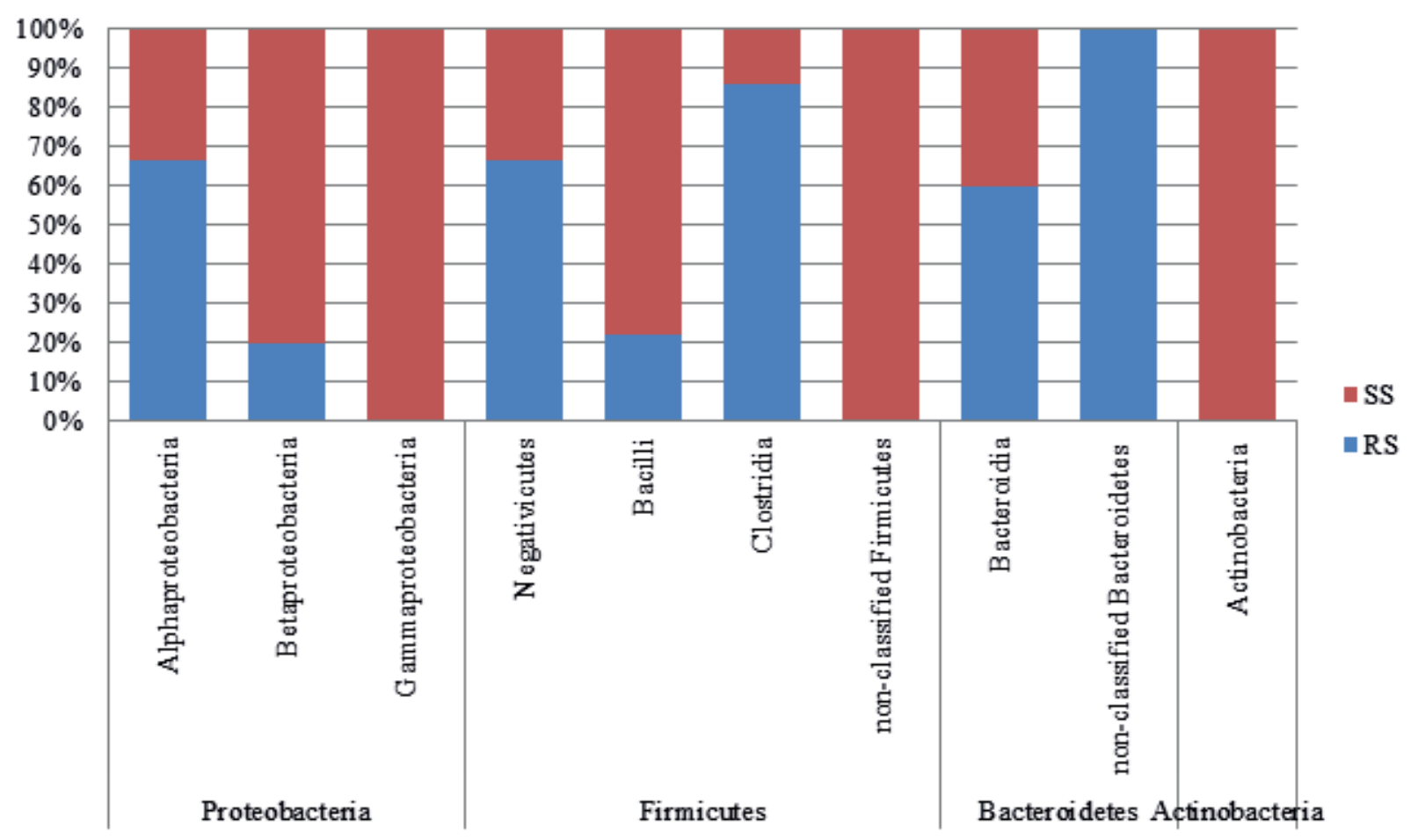

The distribution of the taxonomic groups at the family level is shown in Table 3. The predominant classes within the Firmicutes phylum in both groups were Negativicutes, Bacilli, and Clostridia. Approximately $90.6 \%$ of sequences from ruminal bacteria belonging to the Firmicutes phylum are 
attributed to the Clostridia class, and the remaining bacteria belonged to Bacilli, Erysipelotrichi, and unclassified Firmicutes (KIM et al., 2011). In this study, within the Clostridia class, Lachnospiraceae and Ruminococcaceae families were present, consistent with the sequences found in ruminal contents (KIM et al., 2011). The Lactobacillales order was the only order found within the Bacilli class.

Rhodospirillales and Rhizobiales were
the predominant orders belonging to the
Alphaproteobacteria class within the Proteobacteria phylum. Within the Betaproteobacteria and Gammaproteobacteria classes, the Burkholderiales order and the Enterobacteriales order were observed, respectively, and present only in the SS group. Only the Bacteroidia class was observed within the Bacteroidetes phylum. According to Kim et al. (2011), among all of the sequences analyzed in the ruminal bacterial community, within the Bacteroidetes phylum, $88.5 \%$ were attributed to the Bacteroidia class.

Sequencing allowed an overall view of the libraries, which was representatively in agreement with data from studies using ruminal and abomasal samples. However, only a small number of clones were analyzed, and therefore, we could not conclude regarding the bacterial diversity in different resistance and susceptibility conditions. Although the results regarding the population were not quantitative, we aimed to identify the qualitative differences of the populations so that future control strategies can be directed to specific microorganisms. According to Leser et al. (2002), the relative abundance of phylogenetic groups may differ considerably between different libraries generated from the same sample due to a small number of analyzed clones or other factors that may affect the PCR amplification. Furthermore, the use of only one primer (EDWARDS et al., 2004; POLZ; CAVANAUGH, 1998), the lack of amplification of certain templates, and the variation in the amplification efficiency among different environmental samples (SKILLMAN et al., 2006) are common occurrences. Moreover, high proportions of the $16 \mathrm{~S}$ rRNA gene for a specific group in a community may indicate that one group is numerically dominant or that one group has the ability to grow faster in comparison to the groups present in that community (BUCKLEY; SCHMIDT , 2003).

\section{Conclusion}

Through the taxonomic identification of the 16S rRNA gene clone sequence, the following predominant phyla were identified in the RS and SS libraries: Firmicutes, Proteobacteria, Bacteroidetes, and unclassified bacteria. Significant differences were observed between the proportions of the bacterial phyla present in the RS and SS groups. To determine the existence of distinct bacterial communities between the groups, additional and complementary analyses are necessary, but this is a first step toward the assessment of the association between the gastrointestinal tract microbiota and nematode resistance in sheep.

\section{Acknowledgements}

Financial support was received from Coordenação de Aperfeiçoamento de Pessoal de Nível Superior (CAPES).

\section{References}

BISHOP, S. C. Possibilities to breed for resistance to nematode parasite infections in small ruminants in tropical production systems. Animal, Cambridge, v. 6, n. 5, p. 741-747, 2012.

BISHOP, S. C.; MORRIS, C. A. Genetic of disease resistance in sheep and goats. Small Ruminant Research, Amsterdam, v. 70, n. 1, p. 48-59, 2007.

BISHOP, S. C.; STEAR, M. J. Modeling of host genetics and resistance to infectious diseases: understanding and controlling nematode infections. Veterinary Parasitology, Amsterdam, v. 115, n. 2, p. 147-166, 2003. 
BISSET, S. A.; MORRIS, C. A.; SQUIRE, D. R.; HICKEY, S. M.; WHEELER, M. Genetics of resilience to nematode parasites in Romney sheep. New Zealand Journal of Agricultural Research, Wellington, v. 37, n. 4, p. 521-534, 1994.

BUCKLEY, D. H.; SCHMIDT, T. M. Diversity and dynamics of microbial communities in soils from agroecosystems. Environmental Microbiology, Oxford, v. 5, n. 6, p. 441-452, 2003.

CUNHA, I. S.; BARRETO, C. C.; COSTA, O. Y. A.; BOMFIM, M. A.; CASTRO, A. P.; KRUGER, R. H.; QUIRINO, B. F. Bacteria and Archaea community structure in the rumen microbiome of goats (Capra hircus) from the semiarid region of Brazil. Anaerobe, London, v. 17, n. 3, p. 118-124, 2011.

EDWARDS, J. E.; MCEWAN, N. R.; TRAVIS, A. J.; WALLACE, R. J. 16S rDNA library-based analysis of ruminal bacterial diversity. Antonie van Leeuwenhoek, Wageningen, v. 86, n. 3, p. 263-281, 2004.

GOOD, B.; HANRAHAN, J. P.; CROWLEY, B. A.; MULCAHY, G. Texel sheep are more resistant to natural nematode challenge than Suffolk sheep based on faecal egg count and nematode burden. Veterinary Parasitology, Amsterdam, v. 136, n. 3-4, p. 317-327, 2006.

GORDON, H. McL.; WHITLOCK, H. V. A new technique for counting nematode eggs in sheep faeces. Journal of the Council for Scientific and Industrial Research, Melbourne, v. 12, n. 1, p. 50-52, 1939.

JACKSON, F.; MILLER, J. Alternative approaches to control - quo vadit? Veterinary Parasitology, Amsterdam, v. 139, n. 4, p. 371-384, 2006.

JAIN, N. C. Schalm's veterinary hematology. $4^{\text {th }}$ ed. Philadelphia: Lea \& Febiger, 1986. 1221 p.

KIM, M.; MORRISON, M.; YU, Z. Status of the phylogenetic diversity census of ruminal microbiomes. FEMS Microbiology Ecology, Amsterdam, v. 76, n. 1, p. 49-63, 2011.

KOTZE, A. C.; O'GRADY, J.; GOUGH, J. M.; PEARSON, R.; BAGNALL, N. H.; KEMP, D. H.; AKHURST, R. J. Toxicity of Bacillus thuringiensis to parasitic and free-living life-stages of nematode parasites of livestock. International Journal for Parasitology, Oxford, v. 35, n. 9, p. 1013-1022, 2005.

LAPORTE-URIBE, J.; GIBBS, S. J. Differential passage of rumen bacterial populations to the abomasum in sheep. Proceedings of the New Zealand Society of Animal Production, Christchurch, v. 69, p. 242-243, 2009.
LESER, T. D.; AMENUVOR, J. Z.; JENSEN, T. K.; LINDECRONA，R. H.; BOYE, M.; MOLLER, K. Culture-independent analysis of gut bacteria: the pig gastrointestinal tract microbiota revisited. Applied and Environmental Microbiology, Washington, v. 68, n. 2, p. 673-690, 2002.

LI, R. W.; WU, S.; LI, W.; HUANG, W.; GASBARRE, L. C. Metagenome plasticity of the bovine abomasal microbiota in immune animals in response to Ostertagia ostertagi infection. PLoS One, San Francisco, v. 6, n. 9, p. e24417, 2011.

O'GRADY, J.; AKHURST, R. J.; KOTZE, A. C. The requirement for early exposure of Haemonchus contortus larvae to Bacillus thuringiensis for effective inhibition of larval development. Veterinary Parasitology, Amsterdam, v. 150, n. 1-2, p. 97-103, 2007.

PATEL, J. K. M.; JHALA, M. K.; SONI, P.; SHABIR, N.; PANDYA, P. R.; SINGH, K. M.; RANK, D. N.; JOSHI, C. G. Molecular characterization and diversity of rumen bacterial flora in indian goats by $16 \mathrm{~S}$ rDNA sequencing. Online Veterinary Journal, Srinagar, v. 6, n. 1, article 77, 2011

POLZ, M. F.; CAVANAUGH, C. M. Bias in templateto-product ratios in multitemplate PCR. Applied and Environmental Microbiology, Washington, v. 64, n. 10, p. 3724-3730, 1998.

ROBERTS, F. H. S.; O'SULLIVAN, P. J. Methods for egg counts and larval cultures for strongyles infecting the gastro-intestinal tract of cattle. Australian Journal of Agriculture Research, Melbourne, v. 1, n. 1, p. 99-102, 1950.

SADDIQI, H. A.; SARWAR, M.; IQBAL, Z.; NISA, M.; SHAHZAD, M. A. Markers/parameters for the evaluation of natural resistance status of small ruminants against gastrointestinal nematodes. Animal, Cambridge, v. 6, n. 6, p. 994-1004, 2012.

SAMBROOK, J.; RUSSELL, D. W. Molecular cloning: a laboratory manual. $3^{\text {th }}$ ed. New York: Cold Spring Harbor Laboratory Press, 2001. 2100 p.

SCHNEPF, E.; CRICKMORE, N.; VAN RIE, J.; LERECLUS, D.; ZEIGLER, D. R.; DEAN, D. H. Bacillus thuringiensis and its pesticidal crystal proteins. Microbiology and Molecular Biology Reviews, Washington, v. 62, n. 3, p. 775-806, 1998.

SHAKYA, K. P.; MILLER, J. E.; LOMAX, L.G.; BURNETT, D. D. Evaluation of immune response to artificial infections of Haemonchus contortus in Gulf Coast Native compared with Suffolk lambs. Veterinary Parasitology, Amsterdam, v. 181, n. 2-4, p. 239-247, 2011. 
SIMCOCK, D. C.; JOBLIN, K. N.; SCOTT, I.; BURGESS, D.; ROGERS, C. W.; PONROY, W. E.; SIMPSON, H. V. Hypergastrinaemia, abomasal bacterial population densities and $\mathrm{pH}$ in sheep infected with Ostertagia circumcincta. International Journal for Parasitology, Oxford, v. 29, n. 7, p. 1053-1063, 1999.

SIMCOCK, D. C.; LAWTON, D. E. B.; SCOTT, I.; SIMPSON, H. V. Abomasal bacteria produce an inhibitor of gastrin secretion in vitro. Research in Veterinary Science, Oxford, v. 81, n. 1, p. 152-157, 2006.

SINNATHAMBY, G. Bacteria associated with Haemonchus contortus. 2012. Thesis (Ph.D. in Science) - Massey University, Palmerston North. Available at: $<$ http://hdl.handle.net/10179/4257>. Accessed at: 20 oct. 2013.

SKILLMAN, L. C.; EVANS, P. N.; STRÖMPL, C.; JOBLIN, K. N. 16S rDNA directed PCR primers and detection of methanogens in the bovine rumen. Letters in Applied Microbiology, Oxford, v. 42, n. 3, p. 222-228, 2006.

SOTOMAIOR, C. S.; DE CARLI, L. M.; TANGLEICA, L.; KAIBER, B. K.; POHL DE SOUZA, F. Identificação de ovinos e caprinos resistentes e susceptíveis a helmintos gastrintestinais. Revista Acadêmica: Ciências Agrárias e Ambientais, Curitiba, v. 5, n. 4, p. 397-412, 2007.
SYKES, A. Parasitism and production in farm animals. Animal Production, Penicuik, v. 59, n. 2, p. 155-172, 1994.

THOMAZ-SOCCOL, V.; SOUZA, F. P.; SOTOMAIOR, C. S.; CASTRO, E. A.; MILCZEWSKI, V.; MOCELIN, G.; SILVA, M. P. Resistance of gastrointestinal nematodes to anthelmintics in sheep (Ovis aries). Brazilian Archives of Biology and Technology, Curitiba, v. 47, n. 1, p. 41-47, 2004.

TIRABASSI, H. T. Identificação molecular de bactérias abomasais associadas a diferentes graus de infecção por Haemonchus contortus em ovinos. 2013. Dissertação (Mestrado em Ciência Animal) - Pontifícia Universidade Católica do Paraná, Curitiba. Available at: <http:// www.biblioteca.pucpr.br/tede/tde_busca/arquivo. php? codArquivo $=3246>$. Accessed at: 8 june 2016 .

TORRES-ACOSTA, J. F. J.; MENDOZA-DE-GIVES, P.; AGUILLAR-CABALLERO, A. J.; CUELLARORDAZ, J. A. Anthelmintic resistance in sheep farms: update of the situation in the American continent. Veterinary Parasitology, Amsterdam, v. 189, n. 1, p. 8996, 2012.

VAN DEN BROM, R.; MOLL, L.; KAPPERT, C.; VELLEMA, P. Haemonchus contortus resistance to monepantel in sheep. Veterinary Parasitology, Amsterdam, v. 209, n. 3-4, p. 278-280, 2015. 
